\title{
The Effect of Internal Control on Performance Accountability in the Main Secretariat of Indonesian Institute of Science
}

\author{
R. Luki Karunia* \\ Business Administration Department \\ Politeknik STIA LAN Jakarta \\ Jakarta, Indonesia \\ *karunialuki@yahoo.com
}

\author{
Diffi Fortuna Heryani \\ Sekertariat Utama \\ Lembaga Ilmu Pengetahuan Indonesia \\ Jakarta Indonesia \\ atharizzki@gmail.com
}

\begin{abstract}
Planning and budgeting reform began in 2005 with Law No. 17 of 2003 concerning State Finance, having implications for the paradigm in the management of state finances, namely that all the state finance must be accompanied by the achievement of output. The purpose of this research was to analyze the influence of internal control on performance accountability in the Main Secretariat LIPI consisting of the control environment, risk assessment and monitoring of the accountability of the performance. The population in this research were all employers at Settama LIPI. Sampling using the Proportionate Stratified Random Sampling technique obtained 132 respondents. The research using Structural Equation Model (SEM) analysis. Based on the results of the research that has been done, the results show that all variables (control environment, risk assessment and monitoring) influence and positively relate to performance accountability. Besides being able to see the influence between variables, from the SEM results it can also see the influence between indicators. The research suggests several things, such as: 1) the application of a policy, should be through a process by involving staff representatives, 2) managing risk while planning, and during and after policy changes, to see whether the policy has a negative or positive impact on performance accountability, and 3 ) carry out continuous monitoring of performance.
\end{abstract}

Keywords-internal control, control environment, risk assessment, monitoring, performance accountability

\section{INTRODUCTION}

\section{A. Background Research}

Performance measurement serves to assess the success or failure of an organization, program or activity. Performance measurement is needed to assess the level of deviation between actual performance and expected performance. By knowing these deviations, efforts can be made to improve and improve performance.

The reason for the importance of measuring the performance of the public sector is related to its responsibility in meeting public accountability and expectations. Public sector organizations are responsible for the use of funds and resources in terms of compliance with procedures, efficiency and achievement of objectives.

Performance measurement in the public sector has several objectives, including:

- Create public accountability. By measuring performance, it will be known whether resources are used economically, efficiently and effectively in accordance with regulations, and can achieve the goals set.

- Knowing the level of achievement of organizational goals. Performance measurement is very important to see whether an organization runs according to plan or deviates from the goals set.

- Improve the performance of subsequent periods. Performance measurement will greatly assist the achievement of organizational goals in the long term and shape efforts to achieve a better work culture in the future.

One guideline for measuring government agencies is the Regulation of the Minister of PAN RB number 25 of 2012, where there are 5 components that must be assessed in LAKIP, namely:

- Performance planning, consisting of strategic plans, annual performance plans, and annual performance determination with a weight of 35 .

- Performance measurement, which includes fulfillment of measurement, measurement quality, and implementation of measurements with a weight of 20 .

- Performance reporting, consisting of fulfilling reports, presenting performance information, and utilizing performance information, is given a weight of 15 . 
- Performance evaluation which consists of fulfilling evaluation, evaluating quality, and utilizing evaluation results, is given a weight of 10 .

- And performance achievement, weighing 20, consists of reported performance (outputs and outcomes), current year's performance and other performance.
Based on the evaluation criteria determined by the Ministry of Education and Culture, LIPI succeeded in getting a performance evaluation like the table 1 below.

TABLE I. THE ASSESSMENT OF LIPI PERFORMANCE

\begin{tabular}{|l|l|l|l|l|l|l|l|l|}
\hline \multirow{2}{*}{ Assessed LKJ Components } & \multicolumn{2}{|c|}{$\mathbf{2 0 1 4}$} & \multicolumn{2}{c|}{$\mathbf{2 0 1 5}$} & \multicolumn{2}{c|}{2016} & \multicolumn{2}{c|}{$\mathbf{2 0 1 7}$} \\
\cline { 2 - 10 } & weight & value & weight & value & weight & value & weight & value \\
\hline Performance Planning & 35 & 26,04 & 30 & 20,51 & 30 & 20,95 & 30 & 21,89 \\
\hline Performance measurement & 20 & 14,80 & 25 & 18,30 & 25 & 18,18 & 25 & 18,26 \\
\hline Performance report & 15 & 11,14 & 15 & 11,14 & 15 & 11,22 & 15 & 11,22 \\
\hline Internal evaluation & 10 & 6,48 & 10 & 6,46 & 10 & 6,82 & 10 & 6,92 \\
\hline Performance achievement & 20 & 12,85 & 20 & 13,47 & 20 & 13,72 & 20 & 14,04 \\
\hline Scores & 100 & $\begin{array}{l}71,31 \\
(\mathrm{~B})\end{array}$ & 100 & $\begin{array}{l}70,15 \\
(\mathrm{BB})\end{array}$ & 100 & $\begin{array}{l}70,89 \\
(\mathrm{BB})\end{array}$ & 100 & $\begin{array}{l}72,33 \\
(\mathrm{BB})\end{array}$ \\
\hline
\end{tabular}

Based on Table 1 can be seen, it can be seen that LIPI has decreased in value from 2014 to 2015 . After the change in the value determination, it can be seen that LIPI continues to increase. Even though LIPI experienced an increase in LKJ assessment, it only rose by a few points.

Based on the background described above, so the research question in this study is how influence the internal control system of the company's performance at LIPI ? Than the purpose of this study is examine and analyze impact the internal control system of the company's performance at LIPI.

\section{B. Operational Variable}

Performance is the output produced by the functions or indicators of an occupation or a profession within a certain time in the organization. Meanwhile, according to Mulyadi [1], Performance is the success of personnel, teams, or organizational units in realizing strategic goals that have been predetermined by the expected behavior.

The research variables contained in the study are:

1) Internal control variable (Variable $X$ ): The internal control variable has 5 (five) elements, but in this study, the writer only took 3 (three) elements that will be used as indicators in this study, namely:

- Control environment (X1), which is a set of standards, processes, and structures that provide the basis for carrying out internal control throughout the organization.

- Risk Assessment (X2), i.e. each entity in facing various risks from external and internal parties. Risk is defined as the likelihood that an event will occur and affects the achievement of objectives.

- Monitoring (Monitoring Activities) (X3), which is a process to assess the quality of internal control performance from time to time. This involves assessing the design and control of operations in a timely manner and taking the necessary corrective actions.

2) Performance accountability variables $(Y)$ : Performance Accountability Assessment, is a picture of the level of achievement of the implementation of an activity / program made in a policy in realizing the goals, objectives, mission and vision of the organization contained in the strategy of an organization. To measure this performance, there are several approaches that will be used, namely by looking at the stages or cycles of this performance measurement. See table 2 below.

TABLE II. OPERATIONAL VARIABEL

\begin{tabular}{|c|c|}
\hline Variabel & \multirow[t]{2}{*}{ Indicator [2-5] } \\
\hline Internal Control & \\
\hline $\begin{array}{l}\text { Control Environment } \\
\text { (X1) }\end{array}$ & $\begin{array}{l}\text { 1. Enforcement of integrity and ethics; } \\
\text { 2. Comittment of competency; } \\
\text { 3. Leadership; } \\
\text { 4. Developing organizational structure as } \\
\text { needed; } \\
\text { 5. Delegation of authorithy and } \\
\text { responsibility; } \\
\text { 6. Policy implementation of human } \\
\text { 7. } \begin{array}{l}\text { Effectively the role of internal control } \\
\text { department }\end{array}\end{array}$ \\
\hline Risk Assessment (X2) & $\begin{array}{ll}\text { 1. } & \text { Establishment the goal of institution } \\
\text { 2. } & \text { Establishment the goal of activities } \\
\text { 3. } & \text { Risk identification } \\
\text { 4. } & \text { Risk Analysis } \\
\text { 5. } & \text { Risk Management } \\
\end{array}$ \\
\hline $\begin{array}{l}\text { Monitoring Activities } \\
\text { (X3) }\end{array}$ & $\begin{array}{ll}\text { 1. } & \text { Monitoring Sustainability } \\
\text { 2. } & \text { Evaluation } \\
\text { 3. } & \text { Audit completion } \\
\end{array}$ \\
\hline $\begin{array}{l}\text { Performance } \\
\text { accountability (Y) }\end{array}$ & $\begin{array}{ll}\text { 1. } & \text { Performance planning } \\
\text { 2. } & \text { Performance implementation } \\
\text { 3. } & \begin{array}{l}\text { Performance review and performace } \\
\text { evaluation }\end{array}\end{array}$ \\
\hline
\end{tabular}




\section{ANALYSIS}

\section{A. Confirmatory Factor Analysis}

The first stage of the analysis carried out in the confirmatory factor analysis is to test the feasibility of the confirmatory model of exogenous variables. The results of the confirmatory factor analysis of exogenous variables can be presented as figure 1 follows.

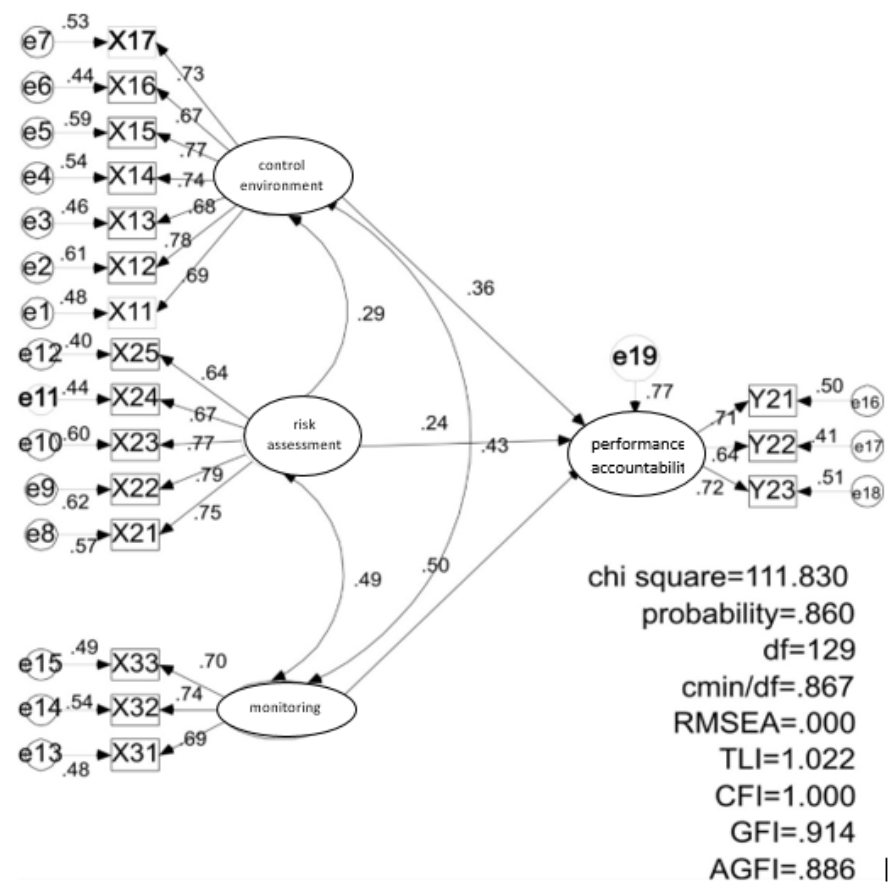

Fig. 1. The results of the confirmatory factor analysis of exogenous variables.

TABLE III. CONFIRMATORY FACTOR ANALYSIS - GOODNESS OF FIT TEST

\begin{tabular}{|l|l|l|l|}
\hline $\begin{array}{c}\text { Goodness-Of-Fit } \\
\text { Index }\end{array}$ & Cut-Of Value & Model Result & Conclusion \\
\hline Chi-Square (df=129) & $(<156,60)$ & 111.83 & Ok \\
\hline Probability & $\geq 0,05$ & 0.860 & Ok \\
\hline RMSEA & $\leq 0,08$ & 0.000 & Ok \\
\hline GFI & $\geq 0,90$ & 0.914 & Ok \\
\hline AGFI & $\geq 0,90$ & 0.886 & Ok \\
\hline CMIN/DF & $\leq 2,00$ & 0.867 & Ok \\
\hline TLI & $\geq 0,95$ & 1.022 & Ok \\
\hline CFI & $\geq 0,95$ & 1.000 & Ok \\
\hline
\end{tabular}

Sources: Primary data are processed

Based on the results of the feasibility test of the confirmatory model of exogenous variables (table 3 ), it is known that the exogenous model can meet the established goodness of fit criteria as indicated by the goodness of fit test value with $\chi^{2}$ of 111.83 with a probability of 0.860 and the feasibility measures of the other models are in the category both of which indicate no difference between the predicted model and observational data. So it can be concluded that the suitability of the predicted model with observational values has met the requirements.

\section{B. Standardized Regression Weight}

See table 4 below.

TABLE IV. STANDARDIZED REGRESSION WEIGHT

\begin{tabular}{|lll|l|}
\hline & & & Estimate \\
\hline X11 & $<---$ & Control environment & .692 \\
X12 & $<---$ & Control environment & .781 \\
X13 & $<---$ & Control environment & .679 \\
X14 & $<---$ & Control environment & .738 \\
X15 & $<---$ & Control environment & .767 \\
X16 & $<---$ & Control environment & .666 \\
X17 & $<---$ & Control environment & .725 \\
X21 & $<---$ & Risk assessment & .752 \\
X22 & $<---$ & Risk assessment & .789 \\
X23 & $<---$ & Risk assessment & .774 \\
X24 & $<---$ & Risk assessment & .665 \\
X25 & $<---$ & Risk assessment & .636 \\
X31 & $<---$ & Monitoring & .690 \\
X32 & $<---$ & Monitoring & .736 \\
X33 & $<---$ & Monitoring & .703 \\
Y21 & $<---$ & Perform Accountable & .706 \\
Y22 & $<---$ & Perform Accountable & .641 \\
Y23 & $<---$ & Perform Accountable & .718 \\
\hline
\end{tabular}

Based on the results of confirmatory analysis of exogenous variables, it shows that the indicators forming each variable show a loading factor value above 0.5 , so it can be concluded that the indicators are declared valid and can be used as forming exogenous variables.

\section{Full Model Analysis}

See table 5 and figure 2 below.

TABLE V. CONFIRMATORY FACTOR ANALYSIS - GOODNESS OF FIT TEST

\begin{tabular}{|l|l|l|l|}
\hline $\begin{array}{c}\text { Goodness-Of-Fit } \\
\text { Index }\end{array}$ & Cut-Of Value & Model Result & Conclusion \\
\hline $\begin{array}{l}\text { Chi-Square } \\
(\mathrm{df}=129)\end{array}$ & $(<156,60)$ & 111.83 & Ok \\
\hline Probability & $\geq 0,05$ & 0.860 & Ok \\
\hline RMSEA & $\leq 0,08$ & 0.000 & Ok \\
\hline GFI & $\geq 0,90$ & 0.914 & Ok \\
\hline AGFI & $\geq 0,90$ & 0.886 & Ok \\
\hline CMIN/DF & $\leq 2,00$ & 0.867 & Ok \\
\hline TLI & $\geq 0,95$ & 1.022 & Ok \\
\hline CFI & $\geq 0,95$ & 1.000 & Ok \\
\hline
\end{tabular}

Sources: Primary data are processe 


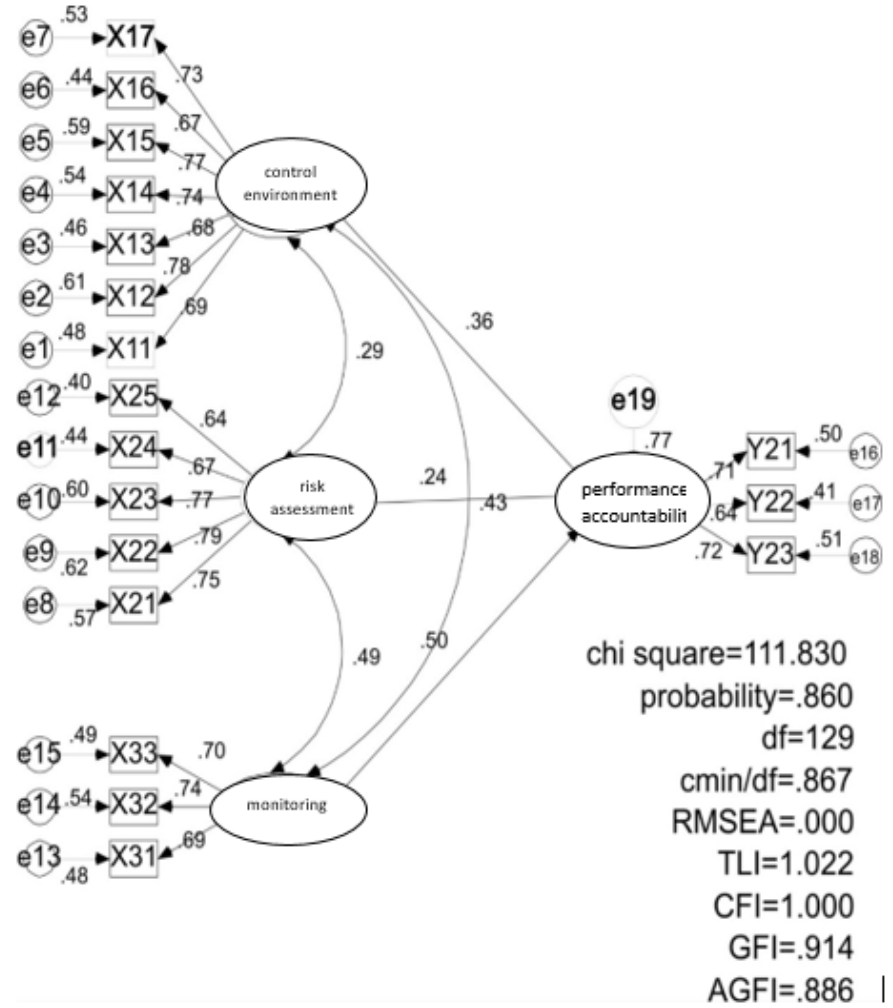

Fig. 2. The results of full model analysis.

The results in the table below show that this model fits according to the data or fits the available data. Chi-square probability index, GFI, AGFI, CFI, TLI, CMINDF and RMSEA are in the expected range of values, which are included in either category. On this basis, it is concluded that this research model meets the size of the model suitability (goodness of fit) and can be continued in further analysis, namely testing the hypothesis.

\section{Hypothesis Test}

This section will present the results of testing the research hypotheses that have been proposed in the previous chapter. Hypothesis testing proposed in this study is based on the Critical Ratio (CR) value of the causal relationship between SEM analysis results. See table 6 below.

TABLE VI. FACTOR ANALYSIS SIGNIFICANCE - PERFORMANCE ACCOUNTABILITY

\begin{tabular}{|l|l|l|l|l|l|l|}
\hline & & & Estimate & S.E. & C.R. & P \\
\hline $\mathrm{Y}$ & $<---$ & $\begin{array}{l}\text { Control } \\
\text { Environment }\end{array}$ & .348 & .097 & 3.578 & $* * *$ \\
\hline $\mathrm{Y}$ & $<---$ & Risk Assessment & .188 & .079 & 2.363 & .018 \\
\hline $\mathrm{Y}$ & $<---$ & Monitoring & .506 & .131 & 3.858 & $* * *$ \\
\hline
\end{tabular}

\section{E. Influence Between Variabels}

The effect of each variable can be seen from the estimation results of the parameters of the direct effect between exogenous variables and endogenous variables. The estimated value of the path coefficient is known in Standardized Regression Weights. While the significance of the effect is known from the value of C.R or the value of probability (p). The results of the analysis of direct effects as a whole are presented in Table 7 following.

TABLE VII. ESTIMATION PARAMETER INFLUENCE BETWEEN VARIABEL WITH SEM

\begin{tabular}{|l|l|l|l|l|l|}
\hline No & Variable X & Variable Y & Estimation & C.R & P \\
\hline 1 & Control Env & Performance & 0.360 & 3.578 & 0.000 \\
\hline 2 & Risk Assesment & Performance & 0.240 & 2.363 & 0.018 \\
\hline 3 & Monitoring & Performance & 0.504 & 3.858 & 0.000 \\
\hline
\end{tabular}

Based on the results of testing of the overall model, then the mathematical model equation can be written in the form of Structural Equation Model (SEM) as follows:

In accordance with the drawings the following summary of the path coefficients between variables. See table 8 below:

\section{TABLE VIII. PATH COEFFICIENT}

\begin{tabular}{|l|l|}
\hline \multicolumn{1}{|c|}{ Variable } & Coeffocient Line \\
\hline Control Environment $\rightarrow$ Corporate Performance & 0.360 \\
Risk Assesment $\rightarrow$ Corporate Performance & 0.240 \\
Monitoring $\rightarrow$ Corporate Performance & 0.504 \\
\hline
\end{tabular}

\section{CONCLUSION AND RECOMMENDATION}

Based on the data analysis that has been done, this research yields the following conclusions: (1) It can be seen from the results of SEM analysis that it can be seen that the control environment significantly influences performance accountability. This is evidenced from the value of the critical ratio (CR) of 3.578 with a probability of 0,000 . So it can be concluded that the environment influences performance accountability. (2) Based on the research results obtained by researchers it can be seen from the results of SEM analysis it can be seen that risk assessment has a significant effect on performance accountability. This is evidenced from the value of the critical ratio (CR) of 2.363 with a probability of 0.018 . So, it can be concluded that risk assessment has a significant effect on performance accountability. (3) Based on the results of research that has been conducted by researchers, it can be seen from the results of SEM analysis that monitoring can have a significant effect on performance accountability. This is evidenced from the value of the critical ratio (CR) of 3.858 with a probability of 0,000 . So, it can be concluded that monitoring has a significant effect on performance accountability. (4) Based on research that has been done, it can also be concluded that the results of previous studies do not have the same results. This is due to differences in the $\mathrm{X}$ variable used. 


\section{REFERENCES}

[1] Mulyadi, Auditing Buku 1. Jakarta: Salemba Empat, 2011.

[2] A.W. Tunggal, Memahami Konsep Pengendalian Internal (Mencegah, Mendeteksi dan Memberantas Kecurangan). Jakarta: Harvindo, 2016.
[3] Committee of Sponsoring Organizations of the Treadway Commission (COSO), Internal Control - Integrated Framework : Executuve Summary, Durham, North Carolina May, 2013.

[4] Mahmudi, Manajemen Kinerja, Sektor Publik. Sekolah Tinggi IlmuManajemen (Edisi ke tiga), YKPN: UPPSTIM YKPN, 2015.

[5] Peraturan Pemerintah No. 80 Tahun 2008, tentang Sistem Pengendalian Internal. 